\author{
Agnieszka Nowak-Lojewska \\ Uniwersytet Gdański \\ agnesa@autograf.pl
}

\title{
Dziecięce konstrukcje świata w rozmowach z dorosłymi
}

\section{Summary \\ Children's constructions of the world expressed in conversations with adults}

The text is based on research carried out among schoolchildren of third class of primary school. It shows a way of thinking about the world typical of children and constructing their social knowledge. The text was produced as a result of series of meetings with schoolchildren of 1-3 classes and the struggle to find answers to their questions of social, existential, ethical and moral nature. It reflects childlike concepts of social knowledge. It is based on quality tests results conveyed with the usage of dialogue method. In the theoretical part there are assumptions of interpretive paradigm and theses about social interactionist theory, linguistic relativism and social and psychological constructivism as a background for the discussion. The concept of the research includes the characteristics and justification for the application of the dialogue method and in addition to that, it gives insight into the results of the research which is the reconstruction of the image of the world typical of children and reconstruction of the meanings given to social ideas by children during their conversations with adults. The research part includes the image of the world constructed by children with excerpts from their utterances, from their ways of understanding the world, their perception of their environment. It is divided into parts entitled: 'Children search', 'Children think', 'Children speak', 'Children construct'. Each part is packed with children's hot knowledge, their experience and their ways of understanding the world.

Słowa kluczowe: wiedza społeczna, rozmowa, rozumienie świata, dzieci

Keywords: social knowledge, conversation, understanding the world, children

Światy dziecięcych znaczeń można ukazywać z różnych perspektyw. W prezentowanym tekście, który jest doniesieniem z badań, wykorzystany został paradygmat interpretatywny i tezy interakcjonizmu społecznego, relatywizmu językowego, a także konstruktywizmu społecznego oraz psychologicznego. Zgodnie z przyjętym tłem teoretycznym nie istnieje świat obiektywnie dany, ale konstruowany w procesie nadawania znaczeń rzeczywistości. Znaczenia te natomiast tworzone są w interakcjach i procesie komunikowania się.

Celem tekstu jest odsłonięcie znaczeń nadawanych światu społecznemu przez dzieci w toku rozmów z dorosłym. Wiąże się to z ukazaniem bogatej wiedzy potocznej dzieci, ich sposobów myślenia o sobie, o innych i o otaczającym świecie, z wykorzystaniem pytań lokujących się w sferze zagadnień obyczajowych, egzystencjalnych, etycznych, moralnych. 
W strukturze tekstu ujmuję to w postaci trzech części. Pierwsza ukazuje założenia paradygmatu interpretatywnego i towarzyszące mu konteksty teoretyczne jako tło prowadzonych rozważań. Część druga to koncepcja badań. Obejmuje ona charakterystykę i uzasadnienie zastosowania metody dialogowej oraz przybliża cel badań, którym jest zrekonstruowanie dziecięcego obrazu świata i znaczeń nadawanych przez dzieci pojęciom społecznym w toku prowadzonych rozmów z dorosłym. Część badawcza zawiera dziecięce konstrukcje świata ilustrowane wypowiedziami dzieci, ich sposobami rozumienia świata, ich spojrzeniem na otaczającą rzeczywistość. Podzielona jest na części zatytułowane: Dzieci poszukują, Dzieci myśla, Dzieci mówia, Dzieci konstruują. Każda z części wypełniona jest tzw. „gorącą wiedzą dzieci”, ich doświadczeniami i sposobami rozumienia świata.

\section{Paradygmat interpretatywny i perspektywy analizy znaczeń}

Zgodnie z założeniami paradygmatu interpretatywnego nie istnieje świat dany obiektywnie, ale jest on konstruowany w codziennych relacjach społecznych, w procesie nadawania znaczeń rzeczywistości, w której ludzie funkcjonują. Ten świat społeczny z jednej strony jest światem konstruowanym przez działanie i wzajemne oddziaływanie ludzi, z drugiej konstrukcja ta jest obdarzona sensem i znaczeniem (Urbaniak-Zając 2009: 26). Oznacza to, że wiedza nie jest jednostce dana, lecz przez nią konstruowana, nie służy ona tworzeniu prawa z myślą o jej kontrolowaniu i przewidywaniu, ale interpretacji i tworzeniu znaczeń. Jest kreacją ludzkiego umysłu (Neuman 1994). Znaczenia tworzą się w interakcji, zgodnie z którą „ludzie interpretują czy „definiują” wzajemnie swoje działania, zamiast na nie po prostu reagować (...). Ludzka interpretacja zapośredniczona jest przez symbole, czy też przez nadawanie znaczeń działaniom innych. Zapośredniczenie to oznacza wprowadzenie procesu interpretacji pomiędzy bodziec a reakcję w zachowaniu jednostki” (Blumer 1984: 71-72). Wynika z tego, że zachowanie jednostki przestaje być zwykłym rezultatem takich sił, jak naciski środowiskowe, bodźce, postawy czy idee, lecz staje się wynikiem sposobu, w jaki jednostka interpretuje i poczyna sobie z nimi w działaniu, które konstruuje.

Istotny w tym procesie jest udział języka, w którym zawarta jest interpretacja rzeczywistości i sposób nadawania światu znaczeń. J. Bartmiński nazywa to ,językowym obrazem świata" (Bartmiński 2009: 11-21), zaś E. Sapir hipotezą relatywizmu językowego (Sapir 1978). W obu przypadkach istnieje związek pomiędzy sposobami używania języka a możliwościami pojmowania świata. Język staje się więc narzędziem komunikowania i konstruowania rzeczywistości, jej rozumienia i nadawania znaczeń.

Mając na uwadze te założenia, każda jednostka ma możliwość budowania własnego sposobu rozumienia świata, odsłaniania bogatego wnętrza doświadczeń i myśli. Tak samo dzieci mają swój świat znaczeń, równie bogaty i interesujący. Zgodnie z założeniami konstruktywizmu poznawczego i społecznego mają kompetencje do bycia aktywnymi uczestnikami procesu uczenia się, wymiany znaczeń, interpretowania świata, siebie, innych i otaczającej rzeczywistości. Poznanie ich sposobów myślenia, doświadczania i badania jest równie inspirujące jak dokonywanie wielkich odkryć. Każde ich pytanie ma bowiem 
podłoże do eksplorowania i rozwiązywania problemów. Są ciekawe świata i jeśli tylko da im się możliwości i warunki, to próbują zdobyć nową dla siebie wiedzę i badać otaczającą rzeczywistość z pasją, zaciekawieniem i chęcią do uczenia się.

\section{Kompetencje dzieci do „filozofowania”}

Nie ma tematów trudnych, na które nie można byłoby dyskutować z dziećmi. Są tylko czasami dorośli, którzy myślą, że dzieci są zbyt małe, aby mogły zrozumieć świat. To zdanie ilustruje poglądy dotyczące stosunku dorosłych do dziecięcego filozofowania. Wśród przeciwników przypisywania dzieciom rozbudowanych kompetencji do filozofowania wyodrębnia się między innymi J. Piageta. Uznawał on myślenie dzieci, szczególnie tych na drugim i trzecim stopniu rozwojowym, za naiwne i prymitywne, pozbawione autorefleksyjności. Dzieci umiejscawiał na poziomie kompetencji wśród ludów prymitywnych, niedostrzegających dualizmu rzeczywistości, spajających materię z duchem. Twierdził, iż dzieci animizują przedmioty, obdarzając je duszą, uznając za tożsame to, co materialne z niematerialnym, kierują się „myśleniem magicznym”. Stąd nie posiadają umiejętności rozumowania formalnego, hipotetycznego, abstrakcyjnego $\mathrm{z}$ wykorzystaniem symboli czy znaków. Przekonywał, że dopiero między 8. a 10. rokiem życia dzieci zaczynają pozbawiać rzeczy świadomości, dualizują rzeczywistość i pojawia się u nich świadomość własnego myślenia. Muszą minąć kolejne lata (11.-14. rok życia), by dojrzewające dziecko osiągnęło zdolność myślenia „wyższego rzędu” (Freese 2008: 43-57).

Odmienne stanowisko prezentuje A. Gopnik (Gopnik 2010), która na podstawie wieloletnich obserwacji i szeregu badań z udziałem dzieci wyprowadza tezę, że dziecięca świadomość świata jest znacznie pojemniejsza niż dorosłych. Dzieci demonstrują swoim zachowaniem altruizm, empatię, kierują się wewnętrznymi zasadami, co z kolei dowodzi dużego poczucia moralności dzieci. Wbrew poglądowi J. Piageta przyjmuje stanowisko, że dzieci dysponują umiejętnością tzw. myślenia kontrfaktycznego (Gopnik 2010), czyli myślenia w kategoriach możliwości, tworzenia alternatywnych światów, hipotetycznych sytuacji, budowania przypuszczeń. Wynika z tego, że dzieci w swoim myśleniu nie tylko nie ograniczają się do „tu i teraz”, do bezpośredniej sytuacji, lecz umieją brać pod uwagę wiele możliwości i oddzielać rzeczywistość od stwarzanych przez siebie światów alternatywnych. Są świadome tego, co mówią i potrafią to komunikować. Werbalizują swoją ciekawość świata licznymi pytaniami kierowanymi do dorosłych i chęcią rozmowy z nimi. Potrafią wnioskować, myśleć przyczynowo-skutkowo, konstruować własne mapy rozumienia pojęć. Ich wiedza nie ogranicza się wyłącznie do świata fizycznego, lecz obejmuje również rzeczywistość psychologiczną. Jak pisze A. Gopnik: „dzieci uczą się, jacy są ludzie, którzy znajdują się wokół nich (...), uczą się psychologii ludzi, którzy je otaczają - szczególnej kombinacji ich przekonan, pragnień, uczuć, cech osobowości, motywacji i zainteresowań (...). W błyskawicznym tempie poznają reguły, których przestrzegają ludzie, wśród których żyją, w tym zarówno arbitralnie przyjęte konwencje, jak i zasady moralne" (Gopnik 2010: 251). Co więcej, dzieci obserwują to, co robimy, słuchają tego, 
co mówimy, konstruują alternatywne hipotezy na temat tego, jaki jest świat, porównują i zestawiają różne jego wersje.

Dodatkowych argumentów uzasadniających gotowość dzieci do wyrażania własnych myśli, refleksji nad sobą i światem dostarcza opisywanie dziecka przez J. Juula jako kompetentnego ,ja” (Juule 2014). Z jego prac wynika, że dziecko to osoba, która jest bacznym obserwatorem, rejestruje różne zachowania, fakty, zdarzenia, jak również wysyła informacje zwrotne, które po uprzednim zinterpretowaniu odsłaniają jego osobisty sposób rozumienia i postrzegania. Jak podkreśla J. Juul, dziecko nie musi dorosnąć, aby być człowiekiem. Ono nim zawsze jest. Rolą dorosłego nie jest wytrenowanie dziecka, ale stworzenie mu warunków, aby miało poczucie wartości i wiarę w siebie. Uznanie kompetencji dziecka nie podważa autorytetu dorosłego, lecz otwiera mu drogę do zdefiniowania siebie i świata bez powielania utartych schematów, lecz myśląc twórczo, refleksyjnie i kreatywnie.

Ze spojrzeniem na dzieci jako osoby kompetentne zgadzają się również D. Klus-Stańska i M. Nowicka (Klus-Stańska, M. Nowicka 2005), które podkreślają, że dziecko nie osiągnie pełni wiedzy o sobie i świecie ,idąc po śladzie”, uczestnicząc w pogadankach, przepisując z tablicy notatki, doszlifowując do perfekcji technikę czytania i pamięciowego liczenia, lecz usprawniając procesy myślowe i wykorzystując mówienie dla uczenia się - mowę eksploracyjną, dziecięce narracje, opowiadanie, zadawanie pytań, mówienie na forum grupy, dyskutowanie z dorosłymi i prezentowanie własnych poglądów i osobistego spojrzenia na świat. To nie tylko cenna droga ich uczenia się, ale również sposób na odkrywanie bogatych zasobów wiedzy osobistej dzieci i własnych sposobów reprezentowania rzeczywistości.

\section{Pomysł na badania}

Poszukując sposobu na werbalizowanie dziecięcych przekonań, sądów, rekonstruowanie ich świata znaczeń, wykorzystałam metodę dialogową. Rozumiana jest ona jako „swobodna rozmowa na określony temat ogólny z uwzględnieniem podporządkowanych mu kilku lub kilkunastu szczegółowych tematów (...). Jest ona wzajemną wymianą myśli i uczuć, w której uczestniczą na różnych prawach osoba przeprowadzająca badania i osoby badane" (Łobocki 2000: 274). Rozmowa ta może przybierać różne formy, np. 1) dyskusji, czyli próby wynegocjowania wspólnego stanowiska przy zaistniałej rozbieżności zdań, 2) wymiany informacji bez usiłowania przewartościowania opinii, przekonań czy postaw, 3) dialogu jako otwarcia się na drugą osobę, 4) prawdziwego interpersonalnego spotkania (Łobocki 2000: 274-275).

W toku badań podejmowałam z dziećmi wszystkie wyżej wymienione formy rozmowy na bardzo różnicowane tematy: te zainicjowane ich ciekawością świata i te zaproponowane przeze mnie, ale wywołane pytaniami dzieci i nadarzającymi się sytuacjami edukacyjnymi i wychowawczymi, co zaprezentuję w dalszej części tekstu. Potraktowałam dialog z nimi nie tylko jako wzmocnienie kompetencji lingwistycznych i konceptualnych, ale również okazję do budowania znaczeń i reprezentowania wiedzy o sobie, innych i otaczającej rzeczywistości. 
Spotykałam się regularnie co 2 tygodnie z grupą uczniów klasy III jednej z gdyńskich szkół podstawowych i prowadziłam z nimi rozmowy. W celu zaciekawienia dzieci, sprowokowania ich do rozmowy, odsłaniania ich sposobów rozumienia świata wykorzystywałam różne rozwiązania, jak: rozmowy w kręgu, burzę mózgów, mapy pojęciowe, pracę w grupach, prezentacje problemowe, projekcje filmów, spotkania z książką.

Celem badań było zrekonstruowanie dziecięcych sposobów rozumienia świata, siebie i innych, gdy punktem wyjścia prowadzonych rozmów były problemy społeczne, egzystencjalne, moralne i inne.

Poniższe rozważania odsłaniają fragment tego, co dzieci mówią, widzą i konstruują. Ukazują ich postrzeganie świata i rozumienie zjawisk w nim zachodzących. Są pełne ekspresji, odsłaniają bogate pokłady wiedzy osobistej dzieci i ich zdolność do refleksyjnego myślenia, tworzenie, analizowania, porównywania, wyciągania wniosków.

\section{Dzieci poszukują}

Badania rozpoczęłam od zadania dzieciom pytania: Jeśli mogłyby decydować o tym, czego chciałyby się uczyć w szkole, jakie bylyby to tematy? Sprowokowało to burzę mózgów, w efekcie której wyłoniły się pytania stawiane przez dzieci i zagadnienia, które są dla nich interesujące. Grupę pierwszą utworzyły następujące pytania:

- Czy przyroda żyje zawsze?

- Jak powstat kosmos?

- Czemu w kosmosie nie ma tlenu?

- Jak się tworzy kolor?

- Jakie sa cechy wszystkich ludzi i czy maja coś ze sobq wspólnego?

- Jak powstała Ziemia?

- Dlaczego ludzie chodza po Ziemi i z niej nie spadaja?

W grupie zagadnień interesujących dzieci znalazły się następujące tematy:

- Alaska - jak tam żyja, jak zdobywaja pożywienie?

- Mont Everest

- Żywioty na świecie

- Prehistoria

- Przywódcy różnych państw

- Hitler

- Uzależnienia: picie alkoholu, narkotyki

- Nasze zdrowie

- Zwierzęta i rośliny

- Wojny na świecie

- Starożytność, średniowiecze i inne epoki. 
Umożliwiło mi to rozeznanie w obszarze dziecięcych poszukiwań poznawczych i ułatwiło dalsze projektowanie spotkań z dziećmi, podczas których kierowałam się pomysłami dzieci i ich zainteresowaniami, aby prawdziwie odzwierciedlić ich świat - świat dziecięcych znaczeń.

\section{Dzieci myślą}

Kolejnym krokiem w badaniach i sposobem pobudzającym dzieci do mówienia, konstruowania znaczeń i odsłaniania ich bogatego wnętrza było tworzenie przez nie mapy myśli. Jej punktem wyjścia było hasło „ŚWIAT”. Dzieci chętnie przystąpiły do zadania, a ich wypowiedzi były zapisywane na tablicy.

W obszarze dziecięcych rozmyślań znalazły się tematy dotyczące:

1) ludzi: ich życia, zdrowia, odżywiania, odpoczywania,

2) rodziny: małżeństwa, dzieci, domu rodzinnego,

3) kontynentów, państw, miast, miasteczek, wsi,

4) zjawisk atmosferycznych, pór roku, zmienności dnia i nocy,

5) przyrody, różnych ekosystemów, fauny i flory,

6) pieniędzy i sposobów ich gromadzenia oraz wydawania,

7) emocji: miłości, dobroci, złości, przyjaźni,

8) wiedzy, myśli, nauki, odkryć i wynalazków,

9) religii, Boga itd.

Przywołane przykłady pokazują wielostronne zainteresowania dzieci zarówno z obszaru tematyki obyczajowej, społecznej, multikulturowej, jak i ekonomicznej, demograficznej, przyrodniczej, moralnej, religijnej. J. Bruner (Bruner 1965; Szuman 1956) ten rodzaj dziecięcej aktywności nazywa ciekawością świata, która wyraża się w dziecięcych pytaniach w celu poznania i lepszego zrozumienia świata, zaś M. Kielar (Kielar 1989) określa to popędem do poznawania świata i zaspokajaniem potrzeb poznawczych dzieci: eksploracji, świeżości, odkrywania. Dla mnie były one natomiast, obok wyżej wymienionych walorów, punktem wyjścia do projektowania rozmów z dziećmi i inicjowania sytuacji aktywizujących. Ciekawość dzieci uczyniłam bowiem osią, wokół której konstruowałam spotkania z nimi, rozmowy, dialogi, dyskusje, debaty, aby usłyszeć ich głos i poznać sposób myślenia.

\section{Dzieci mówią}

Tematy zaproponowane przez dzieci doprowadziły do ciekawych rozmów. Spotkanie na temat Przywódcy różnych państw (Hitler) sprowokowało rozmowy o wojnie. Temat Nasze zdrowie zakończył się rozmowami o chorobach, a klasowe sytuacje - nieporozumienia między uczniami były wstępem do dyskusji o kłamstwie. Rozmowy o wojnie odsłoniły obraz wroga i przyczyny wojen. Dziecięce rozumowanie ilustrują poniższe wypowiedzi:

Obraz wroga:

- osoba, której nie lubimy. Chcemy z nia walczyć,

- osoba przeciwko nam, 
- to ktoś, do kogo nie masz zaufania,

- to osoba przez nas znienawidzona,

- przeciwnik dobrych,

- to ktoś na kogo jesteśmy źli,

- to osoba, która chce zabić druga osobę,

- to osoba zła,

- przeciwnik.

Dlaczego ludzie walczą?

- dlatego, że się nie lubia i nie zgadzaja ze soba,

- bo sa chciwi,

- bo myśla, że to dobre rozwiazanie, żeby zakończyć kłótnię,

- bo chca zdobywać inne kraje,

- bo państwa kłóca się ze soba i zaczynaja walczyć,

- bo ludzie nie lubia się, walcza tylko o swoje i nie umieja dojść do porozumienia,

- bo chca być najlepsi.

W każdej z tych wypowiedzi zawarty jest sens, dziecięcy sposób postrzegania. Może brakuje im poprawności oczekiwanej przez dorosłego, ale mają one treść. Istota pojęcia została wyrażona. Dodatkowo dzieci wzmacniały swoje wypowiedzi opisem aktualnej sytuacji politycznej Polski, jej relacji z sąsiadami i zagrożeniem posłużenia się przez mocarstwa bronią atomową. W dyskusjach pojawiły się nazwiska kluczowych polityków, jak: W. Putin, B. Obama, A. Duda. Wypowiedzi były poparte przykładami i argumentami. Na zakończenie naszego spotkania przeczytaliśmy książkę D. Cali i S. Blocha pt. Wróg (Cali, Bloch 2012), która sprowokowała dzieci do pytań, np.: Kim jest wróg dla wroga? Czy każdy wróg jest taki sam? Jakie sa rodziny wrogów? Kto sprawia, że ludzie walczą?

W efekcie aktywności dzieci powstały też prace plastyczne wyrażające ich sposób myślenia o wojnie.

Rozmowy o kłamstwie skupiły się wokół pytania Co to jest kłamstwo? Dzieci najczęściej odpowiadały:

- to coś, co można zgonić na druga osobę,

- to mówienie nieprawdy ze strachu,

- to nieprzyznawanie się do winy,

- to niemówienie prawdy,

- to nieprawda wobec innych,

- to nieprzyznawanie się do winy i zrzucanie winy na kogoś innego.

Drugie pytanie prowokujące do rozmowy brzmiało: Dlaczego ludzie kłamia? Tu argumentacja dzieci przyjęła następującą postać:

- ponieważ boja się przyznać do winy,

- boja się prawdy,

- bo się boja, 


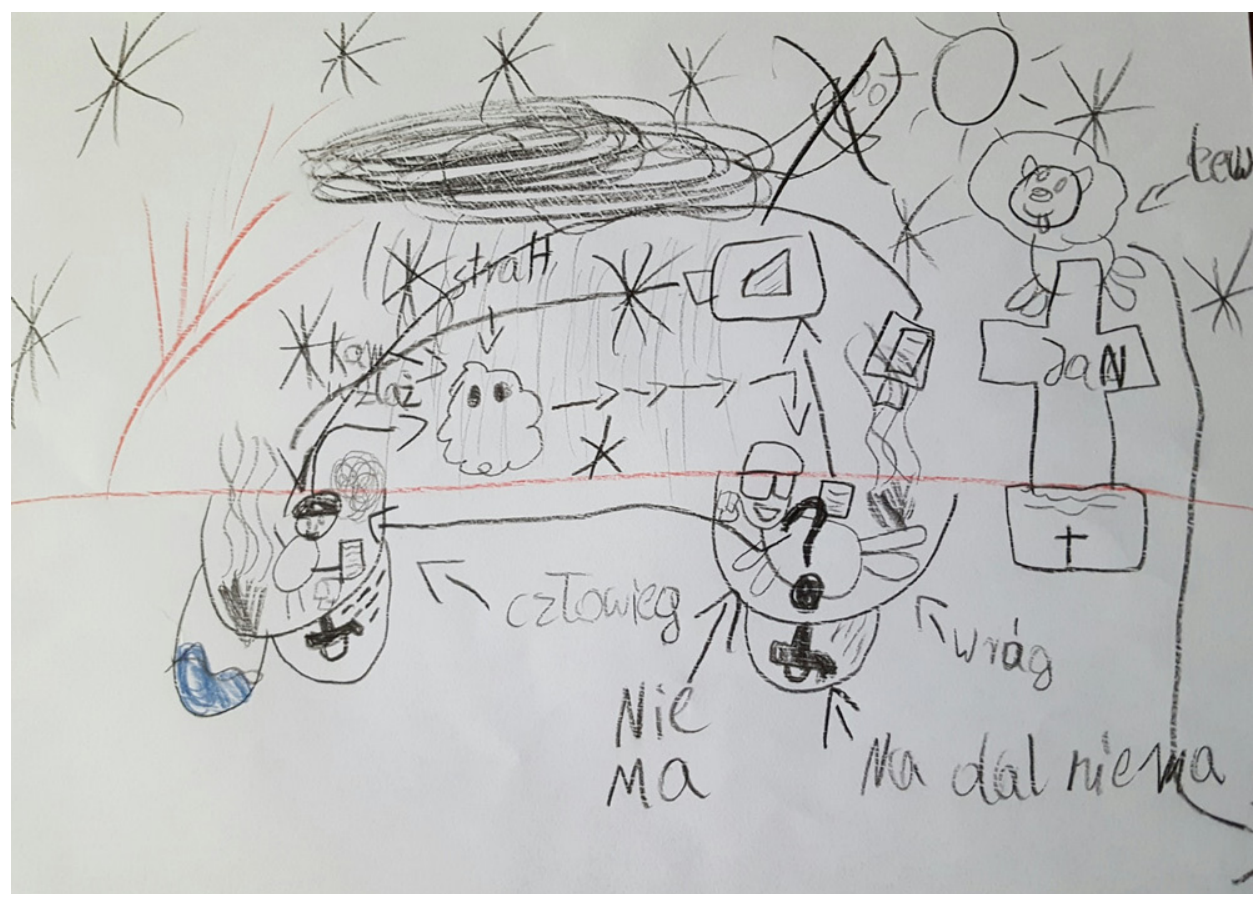

Fot. 1. Wojna według dzieci

Źródło: Materiały własne.

- bo boja się kary,

- bo chca coś ukryć,

- bo chca kogoś nie zranić,

- bo nie chca być niemili.

Przyglądając się wypowiedziom dzieci, można w nich uchwycić zarówno dziecięce definiowanie kłamstwa, jak i motywy posługiwania się nim przez ludzi. Dzieci w swoim języku wyłoniły znane w literaturze przedmiotu (Brenifier 2010) kategorie, jak: kłamstwo ze strachu, kłamstwo dla przyjemności, kłamstwo dla uniknięcia kary, kłamstwo złośliwe, kłamstwo dla korzyści oraz kłamstwo „,białe”. Zauważyły również, że kłamstwo utrudnia życie, bo gdy prawda wyjdzie na jaw, wszystko się komplikuje, burzy się zaufanie i przychodzi ból.

W rozmowach z dziećmi poruszyliśmy również temat chorób. Wprawdzie punktem wyjścia były rozmowy o naszym zdrowiu, ale dzieci niemal samoczynnie przeszły do przykładów różnych chorób, w tym cywilizacyjnych i chęci dowiedzenia się o nich więcej. W odpowiedzi na dziecięce zainteresowania posłużyłam się tekstem duńskiej autorki pt. Brenda ma smoka w swojej krwi (Engelhard 2003; Eliassen, Forslinol 2002) opisującej historię kilkuletniej dziewczynki zakażonej wirusem HIV. O bohaterce dowiadujemy się również, że została zaadoptowana, bo jej rodzona matka zmarła z powodu AIDS, że ma 
kilkoro przybranego rodzeństwa i że mimo choroby chce być szczęśliwa i nieodrzucana przez innych ludzi. Po lekturze tekstu zadałam dzieciom dwa pytania: Jaki problem miała Brenda? Kim byt smok we krwi Brendy?

Od dzieci usłyszałam następujące odpowiedzi:

- byta chora na Hifa,

- mogła umrzeć tak, jak jej mama.

- prawie każdy ja odrzucat, bo bat się smoka w jej krwi.

- nikt nie chciat się z nia bawić.

- bała się szpitala i choroby.

Podczas wypowiedzi dzieci nie było strachu, ale zaciekawienie wyrażające się w ich pytaniach. Jedne pytały: Co to jest HIV? Inne odpowiadały im natychmiast, że to niebezpieczna choroba, na którą ludzie umierają. Były też pytania, jak można się nią zarazić i jak pomóc Brendzie, żeby ludzie się nie bali jej i choroby. W odpowiedzi usłyszałam:

- pocieszać ja i przytulać,

- zaprzyjaźnić się z niq i bawić,

- nie odrzucać jej z powodu choroby,

- dać pieniadze na leczenie,

- przypominać o braniu leków,

- dodawać odwagi przy pobieraniu krwi i robieniu zastrzyków,

- traktować ja jak normalna dziewczynkę.

Po rozmowach $\mathrm{z}$ dziećmi i rozeznaniu ich wiedzy osobistej w tym zakresie zdecydowaliśmy, że warto dowiedzieć się więcej na temat profilaktyki AIDS, aby wiedzieć, jak rozsądnie postępować, dbając o własne zdrowie i nie narażając ludzi chorych na nieprzyjemne i upokarzające dla nich sytuacje. Ponadto dzieci chciały wiedzieć więcej o cukrzycy, białaczce oraz innych chorobach cywilizacyjnych XXI wieku.

\section{Dzieci konstruują}

Jednym ze sposobów myślenia o dziecku jest dyskurs konstruktora/kontestatora (Klus-Stańska 2007: 101-106). Zakłada on, że dziecko jest kompetentne intelektualnie i obiecujące twórczo. Jest zdolne do rozumienia zjawisk i procesów, ich analizowania, oceniania, „nadawania osobistych znaczeń, już nie tylko w zetknięciu ze środowiskiem materialnym (co dominowało w ujęciach Piagetowskich), lecz także w warunkach eksplorowania zjawisk społecznych $\mathrm{w}$ dynamicznych kontekstach interpersonalnych (...). Dziecko nie tyle pilnie słucha dorosłego, by od niego dowiedzieć się, jak jest, ale obserwuje go badawczo, a czasem eksperymentalnie prowokuje do różnych zachowań, by z nich wywnioskować o naturze rzeczywistości społecznej” (Klus-Stańska 2007: 101-102). Dorosły ma wówczas za zadanie stworzyć dziecku sprzyjające poznawczo warunki do ujawniania bogatych zasobów wiedzy osobistej i jej wykorzystywania w tworzeniu nowych, już na wyższym poziomie struktur poznawczych. Dzieci wówczas konstruują swoją wiedzę, a dorośli przestają być tymi, którzy kierują ich procesem uczenia się i narzucania znaczeń. Obie strony 
negocjują i ujawniają swoje opcje i racje, próbują wyrażać swoje myśli i podejmują wysiłek zrozumienia cudzego stanowiska, innej niż własna argumentacji. Dzięki temu osiągają postępy w uczeniu się.

W toku prowadzonych badań starałam się, aby dzieci miały okazję bycia konstruktorami własnej wiedzy. Wspólnie negocjowaliśmy tematy. Podczas rozmów tak dzieci, jak i ja ujawnialiśmy swoje sposoby myślenia o świecie, innych i otaczającej rzeczywistości. Wypowiadaliśmy swoje racje, argumenty i stanowiska. Byliśmy otwarci na siebie. W zamian za to dzieci odsłonimy mi fragment swojego tajemniczego wewnętrznego świata, obdarzyły zaufaniem i odwdzięczyły się zainteresowaniem i zaangażowaniem podczas zajęć.

\section{Podsumowanie}

Podczas spotkań z dziećmi prowadziłam rozmowy jako „ten dorosły”, ale nie „ten lepszy”. Starałam się obdarzyć je szacunkiem i zaufaniem do ich kompetencji. I nie zawiodłam się. W wielu sytuacjach dzieci zaskakiwały mnie pomysłowością pytań, świadomością problemu i oryginalnością rozwiązań. Może niekiedy ich wypowiedzi były proste i czasami niepoprawne językowo, ale zawsze zawierały w sobie autentyzm, prawdę i głęboką mądrość. Dyskutując z nimi na tematy społeczne, moralne, etyczne, obyczajowe i inne zaakceptowałam wybory i interpretacje dzieci zgodnie z zasadą „mają prawo tak myśleć” (Gopnik 2010: 104). Słuchałam uważnie ich, a one mnie, zapraszając się w ten sposób wzajemnie do wspólnego odkrywania świata. Każda z rozmów była nowym motywem do uczenia się i otwarciem się na drugiego człowieka. Zniknęła w nich potrzeba upodabniania się do kogokolwiek na rzecz samodzielnego myślenia, refleksji i zaciekawienia oraz krytycznego rozumienia rzeczywistości bez jej idealizowania, ale realnego traktowania z postawą gotowości do zmiany.

\section{Literatura}

Bartmiński J. (2009), O pojęciu językowego obrazu świata. W: J. Bartmiński (red.), Językowe podstawy obrazu świata. Lublin, Wydawnictwo UMCS.

Blumer H. (1984), Społeczeństwo jako symboliczna interakcja. W: Mokrzycki E. (red.), Kryzys i schizma. Cz. 1, Warszawa, PIW.

Brenifier O. (2010), Prawda wedtug Niny. Warszawa, Wydawnictwo Czarna Owca.

Bruner J. (1965), Proces ksztatcenia. Warszawa, PWN.

Cali D., S. Bloch (2012), Wróg. Poznań, Zakamarki.

Engelhard J.B. (2003), More er stadia en engel. Kros Forlag.

Eliassen S., Forslinol A. (2002), Mar har modt en fyr. Thorup.

Freese H-L. (2008), Nasze dzieci sa filozofami. Jak rozmawiać z dziećmi o poważnych sprawach. Kraków, WAM.

Gopnik A. (2010), Dziecko filozofem. Co dziecięce umysty mówia nam o prawdzie, mitości oraz sensie życia. Warszawa, Prószyński i Ska. 
Juule J. (2014), Twoje kompetentne dziecko. Dlaczego powinniśmy traktować dzieci poważniej? Tłum. B. Hellman, B. Baczyńska, Podkowa Leśna, Wydawnictwo MiND.

Kielar M. (1989), Potrzeby i możliwości poznawcze dziecka „Wychowanie w Przedszkolu”, nr 1.

Klus-Stańska D. (2007), Między wiedza a władza. Dziecięce uczenie się w dyskursach pedagogicznych „Problemy Wczesnej Edukacji”, nr 1/2 (5/6).

Klus-Stańska D., M. Nowicka (2005), Sensy i bezsensy edukacji wczesnoszkolnej. Warszawa, WSiP.

Łobocki M. (2000), Metody i techniki badań pedagogicznych. Kraków, Oficyna Wydawnicza „Impuls".

Neuman W.L. (1994), Social research methods. Qalitative and quantitative approaches. BostonLondon, Allyn and Bacon.

Sapir E. (1978), Kultura, język, osobowość: wybrane eseje. Tłum. B. Stanosz, Warszawa, PIW.

Szuman S. (1956), Aktywność własna jako czynnik rozwoju dziecka w okresie 7-14 lat. „Nowa Szkoła", nr 6.

Urbaniak-Zając D. (2009), O problemach towarzyszacych badaniom jakościowym. „Problemy Wczesnej Edukacji”, nr 2. 